\title{
NEEDS OF ADULTS EDUCATION STAKEHOLDERS
}

\section{RESEARCH STUDY/REPORT}

Aleksander Kobylarek, Luba Jakubowska, Kamil Błaszczyński, Noémie Govindin, Piera Sciama, Alcidio Jesus, Claudia Amaral, Samuel Yosef, Amelia Fiorillo 


\section{NEEDS OF ADULTS EDUCATION}

STAKEHOLDERS

\section{RESEARCH STUDY/REPORT}

Aleksander Kobylarek, Luba Jakubowska, Kamil Błaszczyński, Noémie Govindin, Piera Sciama, Alcidio Jesus, Claudia Amaral, Samuel Yosef, Amelia Fiorillo 
The publication prepared as a result of The Erasmus + Strategic Partnership Project in the Field of Adult Edu cation titled Needs of adults education stakeholder

( $\mathrm{N}^{\circ}$ 2019-1-PLo1-KA204-065792) with experts from

the consortium organizations: FUNDACIA PRO SCIENTI

PUBLICA (Poland), ITAKA TRAINING (Italy), E-SENIORS: IN-

TIATION DES SENIORS AUX NTIC ASSOCIATTON (France) and

AFN ACADEMIA FORMAÇ̃̃o Do NORTE (Portugal).

AUTHORS:

Aleksander Kobylarek, Luba Jakubowska, Kamil Bła-

szczyński, Noémie Govindin, Piera Sciama, Alcidio

Jesus, Claudia Amaral, Samuel Yosef, Amelia Fiorillo

STATISTICAL EDITORS:

Kamil Blaszczyński, University of Wroclaw, Polan

REVIEWEN

Tijana Milenkovic Jankovic, the UK

Patrycja Karpińska, Poland

DESIGN AND DTP

Hanna Whoch, Poland

PUBLISHER:

Foundation Pro Scientia Publica

Ul. Redycka 37, 51-169 Wroctaw

www.proscientiapublica.pl
The European Commission's support for the production of this publication does not constitute an endorsement of the contents, which reflect the views only of the authors, and the Commission cannot be held responsible for any use which may be made of the information contained therein.

February 2021

Creative Commons Attribution 4.0 Internationa

Authority code: CC_BY_4_o

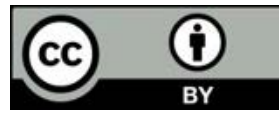

ISBN 978-83-953451-4-2

doi: 10.15503/andr.2021.neon.en

Photo by

CoWomen ; Green Chameleon ; krakenimages

Marten Bjork ; Sarah Dorweiler ; You X Ventu

on Unsplash
Introduction 4

Results 10

summary 24

References 30

Annexes 34

Annexe1 36

Annexe 1140

TABLE OF CONTENTS 
1. Introduction

\section{INTRODUCTION}

we 
The project "Needs of adults education stakeholders" ( $\mathrm{N}^{\circ}$ 2019-1-PLo1-KA204-065792) was created in response to the lack of tools measuring the educational needs of the Adult Education (AE) staff. Despite the vigorous development of andragogy methodology, the field still lacks in its own research tools: andragogy uses tools from other related fields, mainly from psychology. Such a solution is not satisfactory, firstly, because many tools have limited access (mainly caused by the necessity to pay usage fee and to have a psychologist working in the team), and secondly, because they are no specific to the study of adult education organisations needs and the educational needs of their employees.

In response to the above demand, the project coordinators developed a questionnair to investigate such needs. The questionnair was translated into other languages and carried out by the project partners. Based on the analysis of the collected responses, a classification of the educational needs of the AE staff was created (Aleksander Kobylarek, Luba Jakubowska, Noémie Govindin Piera Sciama, Alcidio Jesus, Claudia Amaral, Samuel Yosef, Amelia Fiorillo).

The presented report contains information about the educational needs and the quantitative evaluation of $\mathrm{AE}$ organisations an NGO workers in the consortium countrie (Poland, France, Italy and Portugal) and other EU and non-EU countries. The research sample contained 1,176 participants. Importantly, the fact that the research was conducted not only in the consortium countries but also in other countries guarantee that the obtained results are symptomatic for European AE sector.
TOOLS FOR DIAGNOSING KEY

COMPETENCES AND NEEDS FOR

CHANGE IN THE ORGANISATION

In order to diagnose education needs, an authorial questionnaire named Adult Education Needs Inventory (AENI) tool was used. The questionnaire is a tool designed to study key competences for the adult education workers (Council of European Union, 2018).

The competence model is inscribed in the concept of life-long learning and it does not focus on the compensation function of the education process; instead, it promotes the insight of educator into self-development and their conscious and active participation therein. AENI was constructed on the basis of the European Union recommendation regarding the 21st century key competences. On the basis of these recommendations, the research team created, tested and evaluated AENI using statistical analysis methods.

The test reliability was confirmed through intercorrelation. The questionnaire reliability was confirmed through factor analysis. Furthermore, the theoretical reliability was inspected through the correlation of FNI with the Social Competencies Profile (РRокоS) (Martowska, Matczak, 2013), which measure the social competencies in the following areas: assertiveness, cooperation, social mindedness, resourcefulness and community awareness. In order to investigate the theoretical reliability, hypotheses were formulated on both correlation of the general scores (from AENI and PROKOS questionnaires) and the selected scales. Correlation studies, in which participated
98 respondents, confirmed the theoretical reliability of AENI questionnaire.

Before the final research, a discriminan analysis was conducted in the form of the Alpha-Cronbach reliability test (with the Alpha-Cronbach reliability test (with high reliability of the created tool (Cronbach's $\alpha=0.846$ ) and its subcategories.

AENI provided relevant information in the form of both individual's general score and scores in six diagnostic sub-categories:

1) communication competences (CC); 2) multi-language and multi-cultural competences (ML\&MC);
3) digital competences (DC); 4) entrepreneurship competences (EC); 5) openness to science and culture (OSC);

6) social and civil competences (SCC).

All of the sub-categories were created by the Polish research team (Kobylarek, Jakubowska, Błaszczyński 2020 - not published yet) and competent judges with the application of the statistical tools such as: 1) principal factor analysis; 2) Cronbach's-alpha reliability test; and 3) the Kendall's W. test of absity test; and 3 ) Cion association. Each individual could achieve a maximum of $100 \%$ from the test in both general and sub-categories scores. The closer was the score to $100 \%$, the less visible were the education needs of the individual.

\section{For this report it is suggested to use the following classification of scores:}

20-44\% - (low score) - strong education needs

$45-75 \%$ (medium score) - average education needs

76-100\% - (high score) - weak education needs 18-item survey was conducted, in which respondents evaluated their organisation. The survey comprised 18 statements representing 18 categories (Table 1), asking the respondents to mark their respective attitude on a 5 -point scale ranging from 'decidedly not agree' to 'decidedly agree'. Item included in the survey were developed based on Herzberg's two-factor theory of motivation for work (source: Bassett-Jones, Lloyd, 2005)

Scores were represented in percentage values. The higher the score an individual obtained, the better his/her opinion about his/her organisation was and the smaller the need for change in the organisation. 
Table 1. Organisation Evaluation Items - List and Description

\begin{tabular}{|c|c|}
\hline Appreciation by employer & An employee feels appreciated by his/her employer. \\
\hline Appreciation by leader & $\begin{array}{l}\text { An employee feels appreciated by his/her direct leader } \\
\text { or supervisor. }\end{array}$ \\
\hline $\begin{array}{l}\text { Achievement of goals for } \\
\text { Organization }\end{array}$ & An employee can achieve goals set by his/her employer. \\
\hline $\begin{array}{l}\text { Achievement of personal } \\
\text { success }\end{array}$ & $\begin{array}{l}\text { An employee has opportunities to achieve his/her perso- } \\
\text { nal success in the organisation. }\end{array}$ \\
\hline Responsibility & $\begin{array}{l}\text { An employee feels a strong responsibility for his/her } \\
\text { tasks. }\end{array}$ \\
\hline Independence & $\begin{array}{l}\text { An employee is given considerable freedom to achieve } \\
\text { the commissioned tasks. }\end{array}$ \\
\hline Advancement & $\begin{array}{l}\text { An employer provides their employee with possibilities } \\
\text { for advancement. }\end{array}$ \\
\hline Personal development & $\begin{array}{l}\text { Current work affects employees' personal development } \\
\text { in a significant and positive manner. }\end{array}$ \\
\hline $\begin{array}{l}\text { Development strategy of } \\
\text { organisation }\end{array}$ & $\begin{array}{l}\text { The organisation of an employee has a clear strategy of } \\
\text { development and employee understands it. }\end{array}$ \\
\hline $\begin{array}{l}\text { Development continuity of } \\
\text { organisation }\end{array}$ & $\begin{array}{l}\text { Organisation continuously aims at its further improve- } \\
\text { ment and puts effort into perfecting and expanding its } \\
\text { activity. }\end{array}$ \\
\hline Workplace & $\begin{array}{l}\text { Organisation provides an employee with an adequate } \\
\text { workplace to complete the commissioned tasks. }\end{array}$ \\
\hline $\begin{array}{l}\text { Comfort of work in organi- } \\
\text { sation }\end{array}$ & $\begin{array}{l}\text { Organisation puts emphasis on employees' comfort of } \\
\text { work. }\end{array}$ \\
\hline Salary & $\begin{array}{l}\text { An employee is satisfied with his/her salary earned in } \\
\text { the organisation. }\end{array}$ \\
\hline Benefits \& bonuses & $\begin{array}{l}\text { Organisation provides an employee with an extensive } \\
\text { range of supplementary benefits and bonuses. }\end{array}$ \\
\hline Relations with boss & $\begin{array}{l}\text { An employee has a good personal relationship with his/ } \\
\text { her employer. }\end{array}$ \\
\hline $\begin{array}{l}\text { Relations with colleagues in } \\
\text { organisation }\end{array}$ & $\begin{array}{l}\text { An employee has good personal relationships with his/ } \\
\text { her colleagues at work. }\end{array}$ \\
\hline Employment security & $\begin{array}{l}\text { Organisation is financially stable and gives an employee } \\
\text { a feeling of employment stability. }\end{array}$ \\
\hline Work and private life & $\begin{array}{l}\text { Tasks conducted in the organisation affect negatively the } \\
\text { private life of an employee. }\end{array}$ \\
\hline
\end{tabular}

(source: Authors own on the basis of: Herzberg, Mausner, Snyderman, 1959)
INTERPRETATION OF THE STUDY

RESULTS ON THE NEED FOR CHANGE

IN ORGANISATIONS

Scores were represented in percentage values. Each item had a minimum score of $0 \%$ and a maximum score of $100 \%$. The higher the score an individual obtained, the better his/her opinion about his/her organisation was. The only exception was the last category focused on work and private life: in ed score was, the weaker the influence of work on one's private life was.

The obtained scores on the evaluation of organisation are recommended to be interpreted as follows:

$\mathbf{0 - 2 0} \%$ - very low opinion of organisation/employer

21-40\% - low opinion of organisation/employer

41-60\% - neutral opinion of organisation/employer

61-80\% - high opinion of organisation/employer

81-100\% - very high opinion of organisation/employer

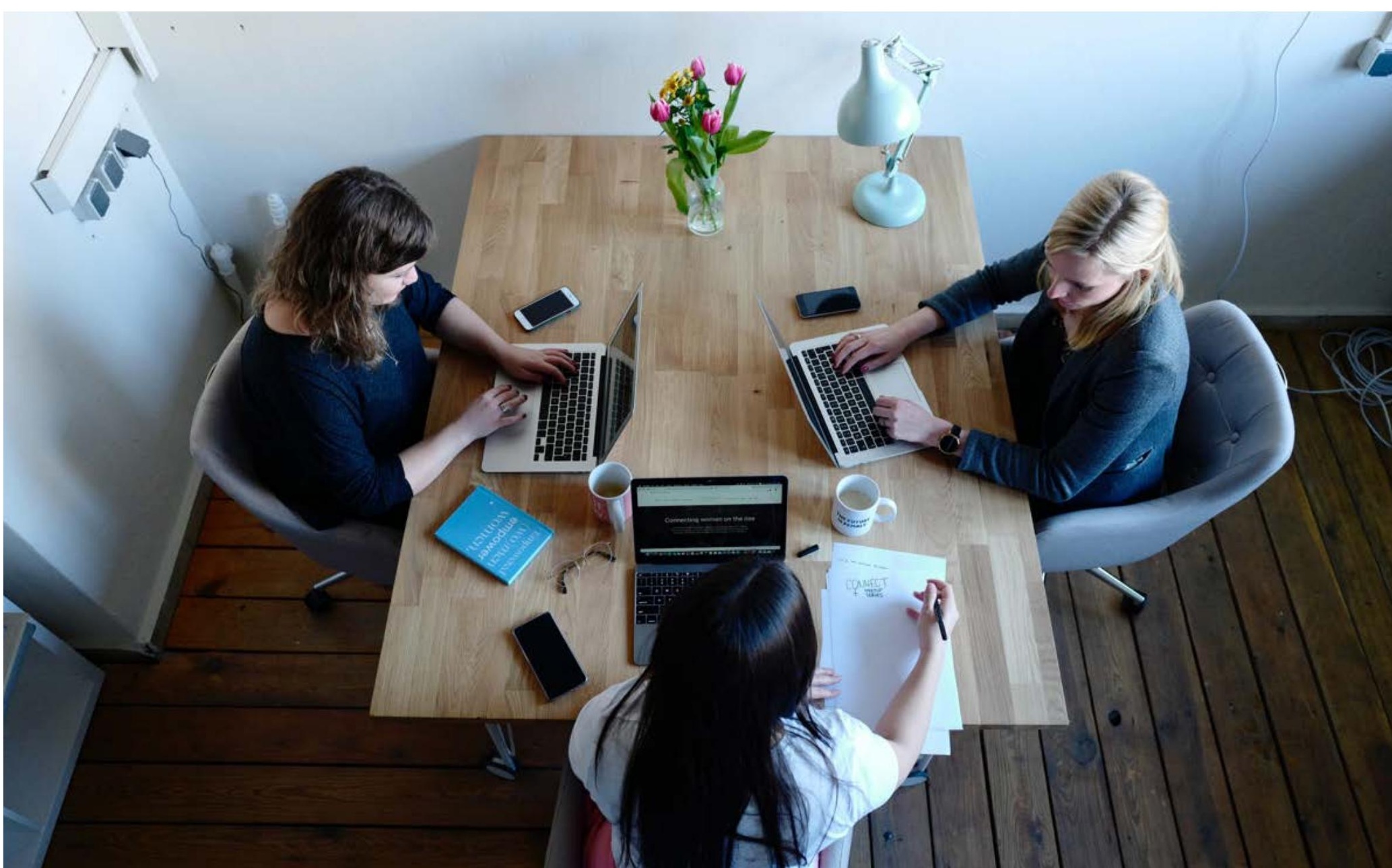


2. Results

\section{RESULTS}

we 
GENERAL RESULTS FOR THE RESPECTIVE COMPETENCES IN AENI TEST

The results of the conducted diagnosis were analysed threefold: 1) the analysis of genera scores obtained by all the study participants 2) the comparison between the scores obtained by participants being formal citizens of EU country and by the participants being formal citizens of non-EU countries; 3) the comparison between the scores obtained

by the project participants: France, Italy, Poland and Portugal. In the study participated 1,176 respondents, whose average general score from AENI test was 78\%, which can be classified as good. Detailed analysis of AENI sub-categories revealed that the lowest score was obtained in entrepreneurship competences $(73 \%)$, which can be classified as high, whereas the highest scores were noted in digital competences $(82 \%)$ and social and civil competences $(81 \%)$, who can be noted as very high.

Figure 1. Adult Education Needs Inventory Test Average sub-category scores

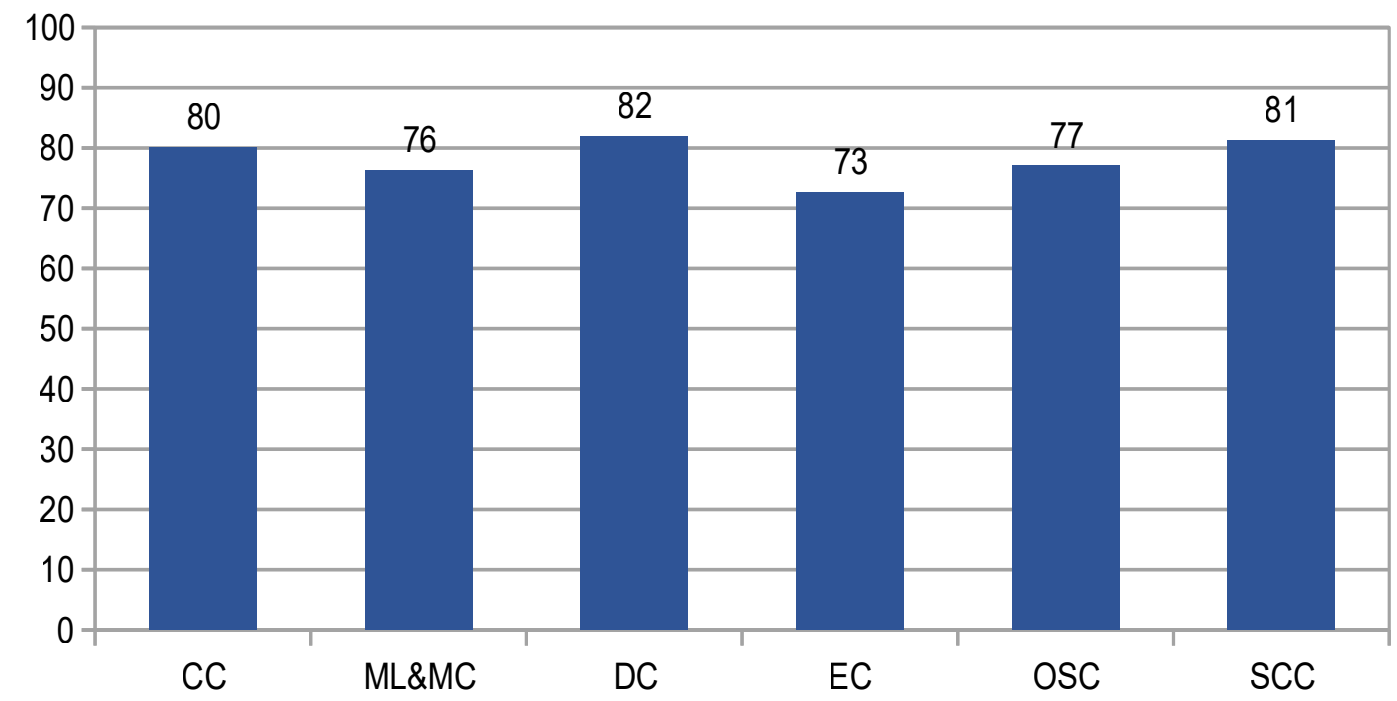

DIAGNOSIS OF THE NEEDS FOR CHANGE IN ORGANISATIONS

Results obtained in the evaluation of organisation survey revealed an average general score of $69 \%$, which can be considere high. Analysis of individual categories revealed that the lowest score was noted in work and private life category, although due to the reversed scale of the category, it can be assumed that most participants confirm that work does not negatively affect their private life, which is a positive phenomenon. Other notably low scores included the categories of salary $(51 \%)$ and benefits and bonuses $(42 \%)$. Therefore, adult educators and NGO workers consider their financia benefits from work to be poor.
Figure 2. Evaluation of Organization Survey

Average subcategory scores

$0 \quad 10 \quad 20$

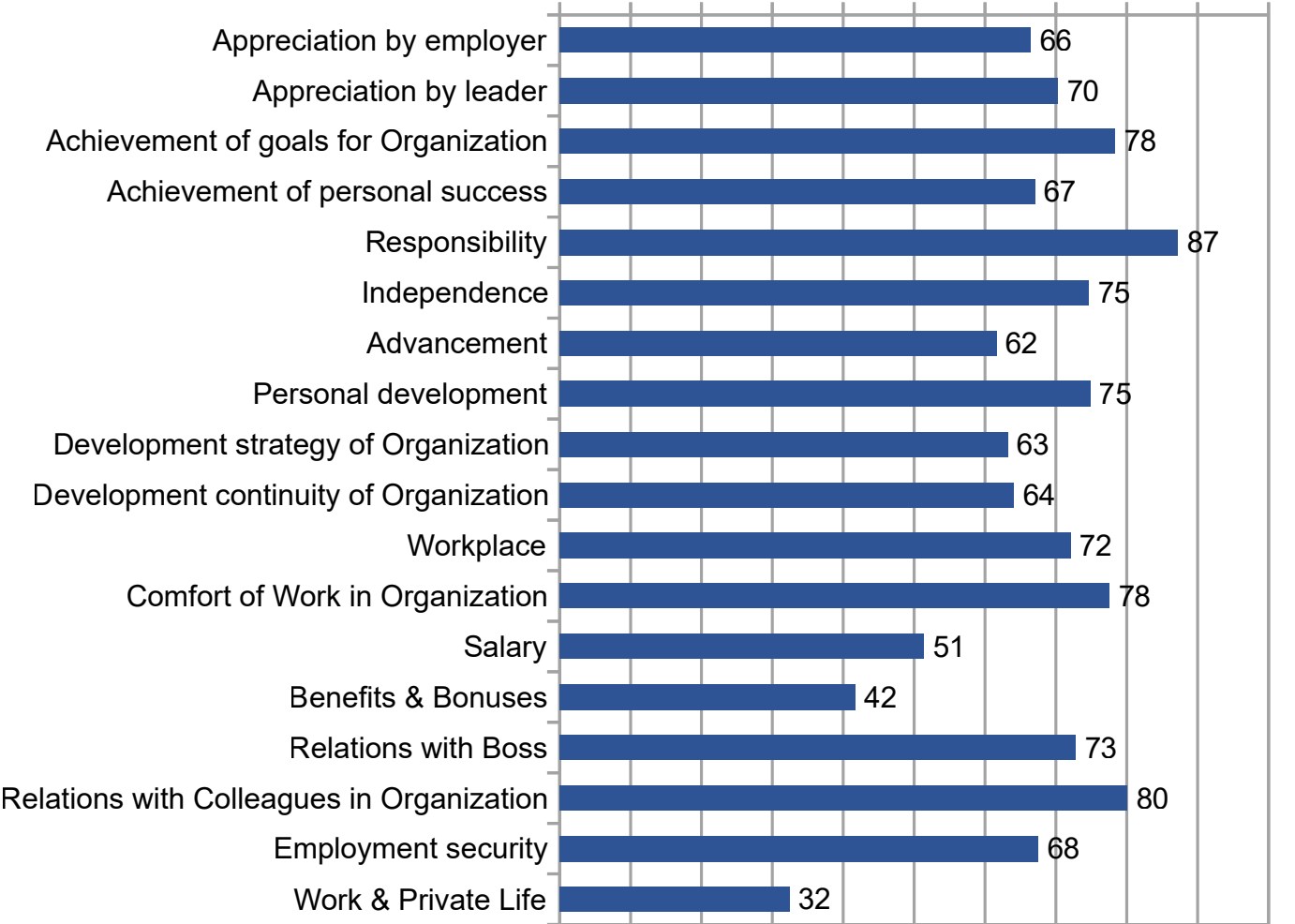

THE COMPARISON OF KEY COMPETENCES' LEVELS BETWEEN EU AND NON-EU RESPONDENTS

In the study participated 1,049 EU respondents and 107 non-EU respondents, hence the disproportion between the two groups is high. The European countries participating in the study were all EU countries except for Luxemburg, whereas the non-EU countries were mainly Turkey, the UK and Ukraine.

The general average score from AENI test for EU participants was $78 \%$ and for non-EU participants was $75 \%$. Thus, the obtained results show that there was a slight differenti- ation of scores, implying that EU adult educators working in the adult education sector are, not by far, more satisfied than their noncused on sub-categories of AENI test revealed the differentiation of scores in communication, digital, entrepreneurship and openness to science categories. In all these categories, higher scores were held by EU respondents. The biggest divergence, amounting to $8 \%$, was noted culture category. Thus, it can be assumed that EU respondents are more satisfied with their communication, digital and especially openness to science and culture competences than their non-EU counterparts. Eu colleagues. The more detailed analysis fo- 
Figure 3. AENI Test Subcategory Scores

EU - non- EU Participants comparison

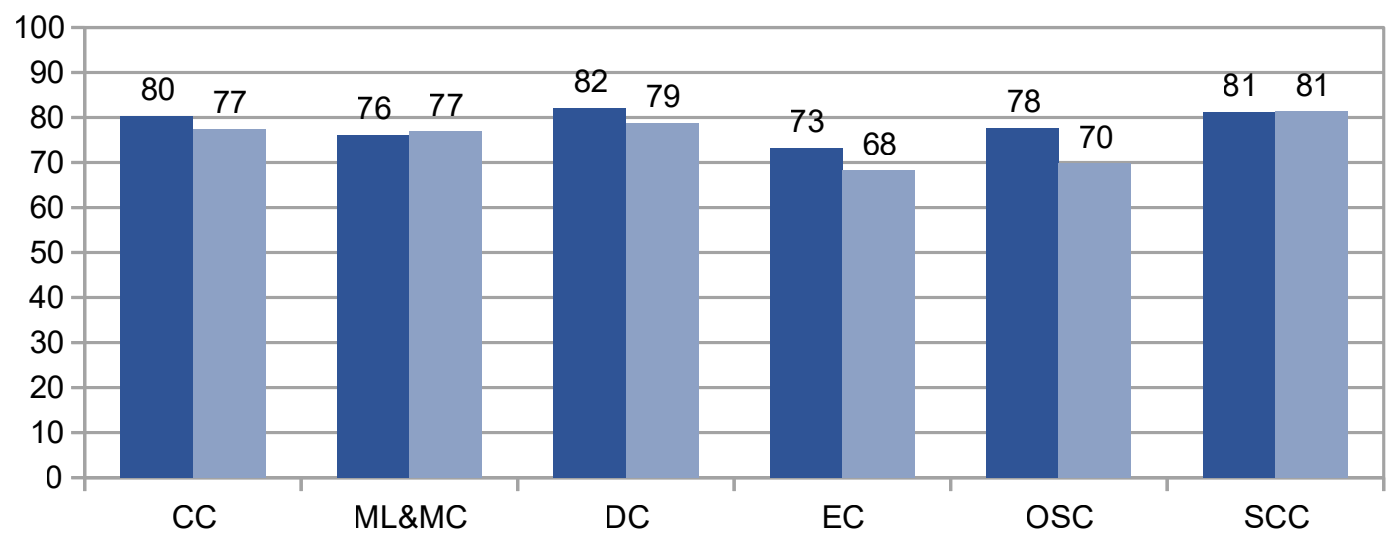

- EU $=$ Non-EU

THE COLLATION OF NEEDS FOR

CHANGE EVALUATION IN EU

AND NON-EU ORGANISATIONS

The evaluation of organisation results obtained in the survey revealed that general average scores were $69 \%$ for EU participants and $67 \%$ for non-EU participants. Thus, Eu respondents were evaluating their organisations slightly more positively than their non-EU counterparts. A more detailed analysis (Figure 4) of individual sub-areas revealed some slight differentiation of scores in all respected categories. The most visible differences were noted in the following areas: the achievement of personal success $(4 \%)$, responsbility (6\%), independence (6\%), advancement (5\%), salary $(5 \%)$, benefits and bonuses (5\%), relations with the boss $(4 \%)$ employment security (6\%) and work and private life (8\%).

On the basis of the comparison, it can be derived that EU respondents assessed their organisations more positively in the categories of responsibility, independence, salary, relationships with the boss, employment security, and work and private life. Non-EU respondents, on the other hand, praised their organisations in such areas as the achieve ccess, advancement and benefits and bonuses.

Therefore, it may be concluded that EU organisations were thought to give their employees a higher degree of responsibility in their work as well as more independence in actions and decision-making, offer them a more satisfactory salary, create more friendly relationships between the employees and their supervisors, give them more stable formal employment and try not to interfere with their employee's private life. Non-EU organizations were thought to give their employees more possibilities in achieving personal success, create more options for advancement, and offer more attractive benefits and bonuses.

Figure 4. Evaluation of Organization

Average scores in categories -EU \& non EU comparison

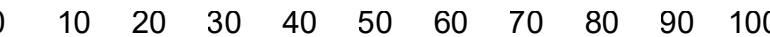

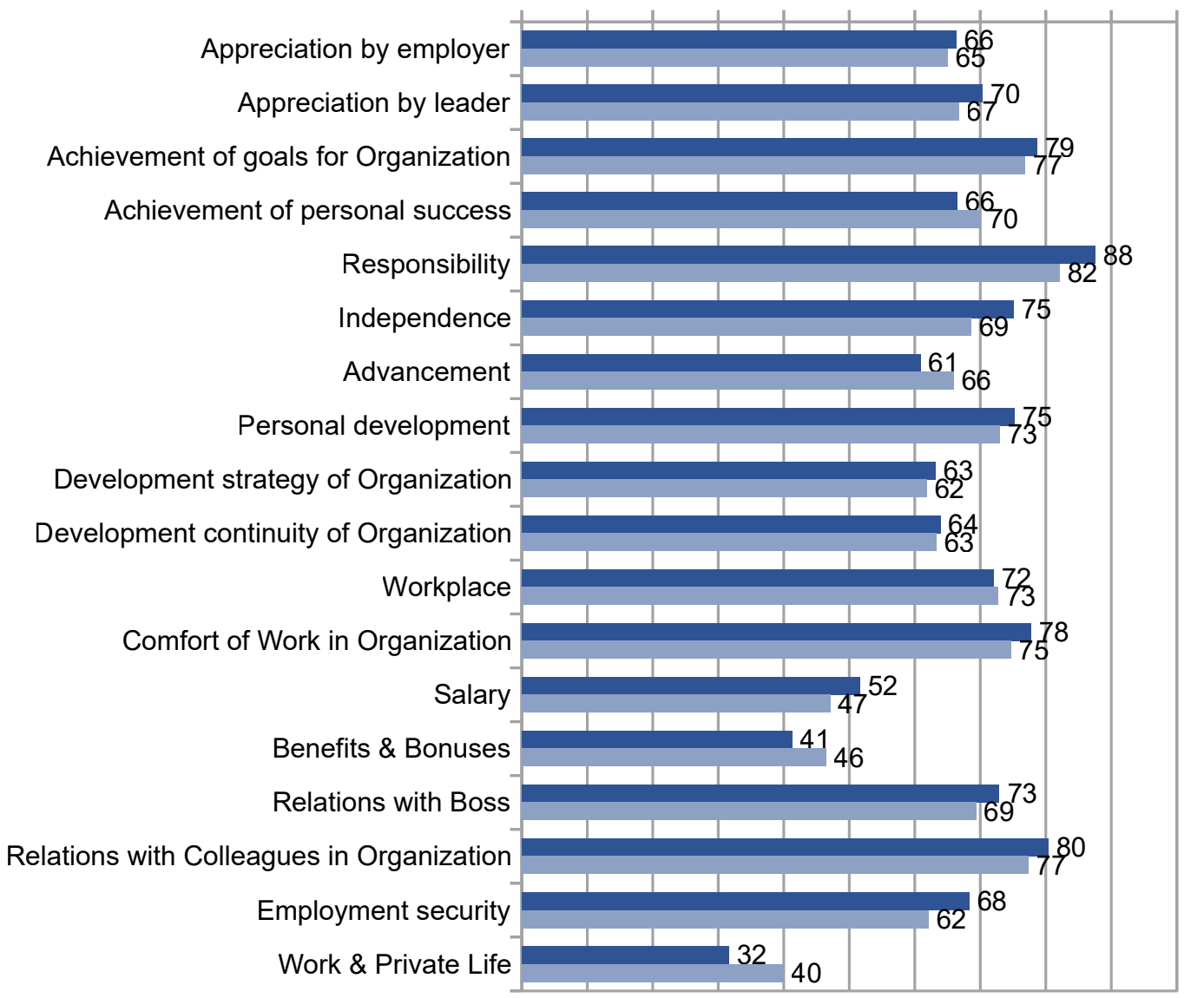

Non-EU $=\mathrm{EU}$

COMPARISON OF THE GENERAL

AVERAGE SCORES OF THE PROJECT PARTNERS' COUNTRIES IN AENI KEY COMPETENCES TES

In the study, there were 201 participant from Portugal, 195 participants from Italy, 135 participants from France and 159 participants from Poland. The comparison of verage results achieved in individual countries (Figure 5) revealed that the highest score was noted in Italy (79\%), very similar yet slightly lower scores were noted in France and Portugal (78\%), and the lowest was noted in Poland (76\%). Although slightly different, the average scores for all countries can be all considered very high. 
Figure 5. AENI Test

Country General Score Comparison

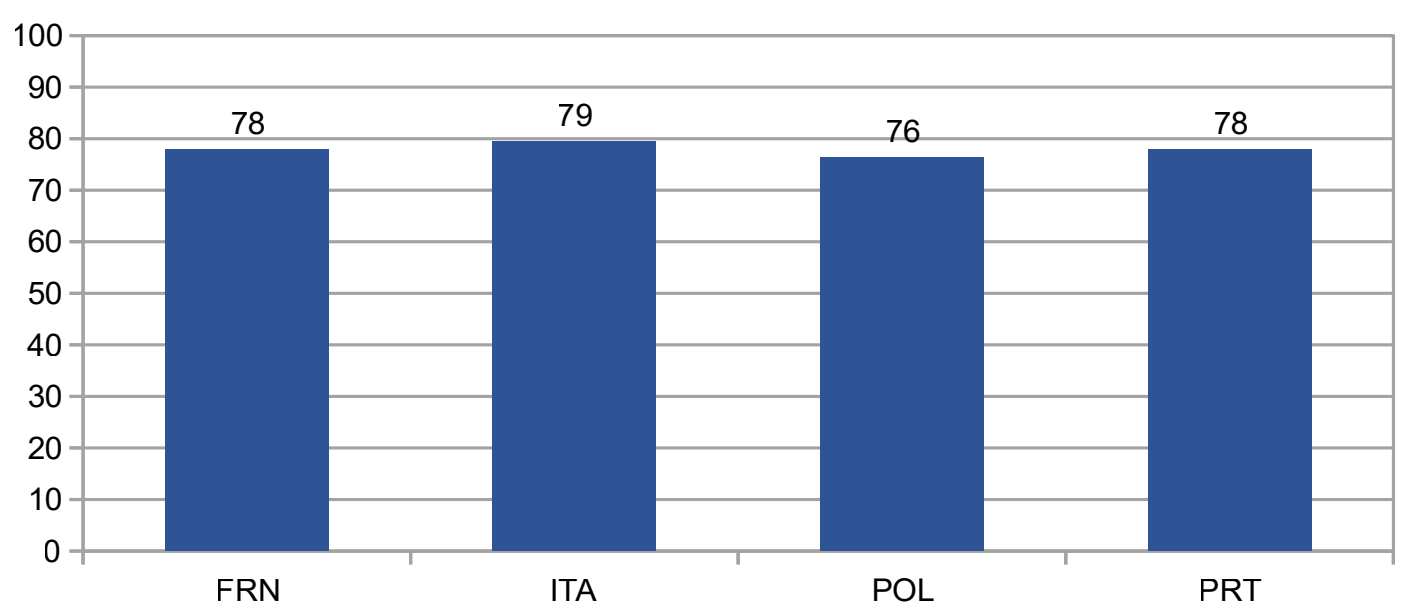

COMPARISON OF THE AVERAGE

SCORES OF THE PROJECT PARTNERS'

COUNTRIES IN AENI TEST FOR TH

RESPECTIVE KEY COMPETENCES

The comparison of the results in the respective categories and their analysis revealed that the biggest diversity in scores was noted in multi-language and multi-cultural and entrepreneur areas. In the category of multi-language and multi-cultural competences, the highest score was obtained by Italian participants $(77 \%)$ and the lowest one by the Polish $(69 \%)$. Average scores were observed in France and Portugal, yet they were closer to scores obtained by Italy. Based on the analysed results, it can be stated that the Polish sample is distinguished by its negative scores among the compared countries. Thus, Polish adult educators and rship competence, where the highest score was again held by Italy $(76 \%)$, whereas the lowest score was once more noted in Poland $(70 \%)$. In comparison to Italy, a lower score was also observed in France (72\%). Although Polish and French results can still be classified as god, they indicate that there are some education needs regarding entrepreneurship competences that require improvement in the eyes of the respondents. A lower score was achieved by the Portuguese respondents ( $75 \%$ ), also in the openness to science and culture

sub-category.

NGO workers may have greater education needs regarding their multi-language and multi-cultural competences.
Figure 6. AENI Test Sub-categories

Country Average Score Comparison

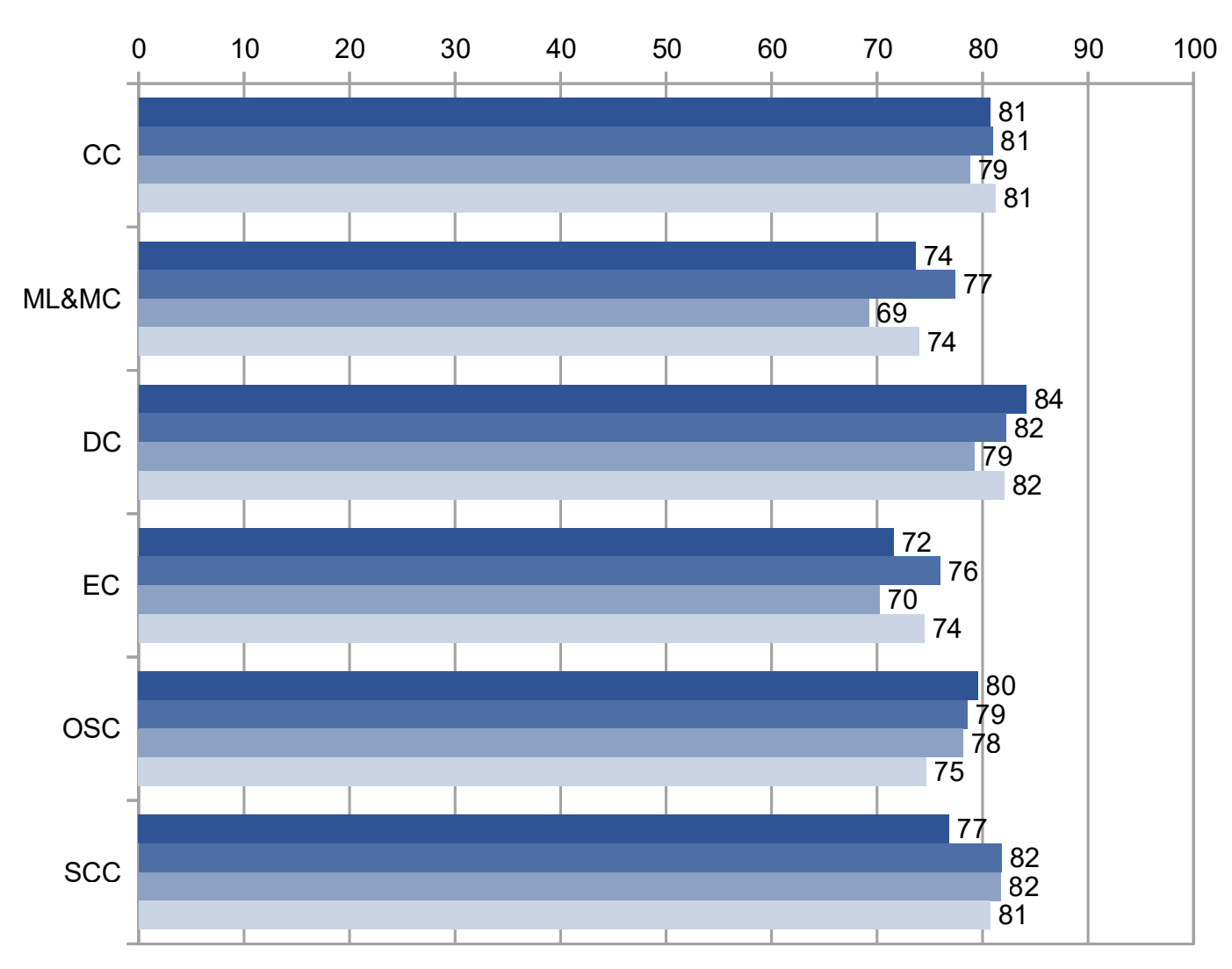

PRT $\square$ POL $\square$ ITA $\square$ FRN

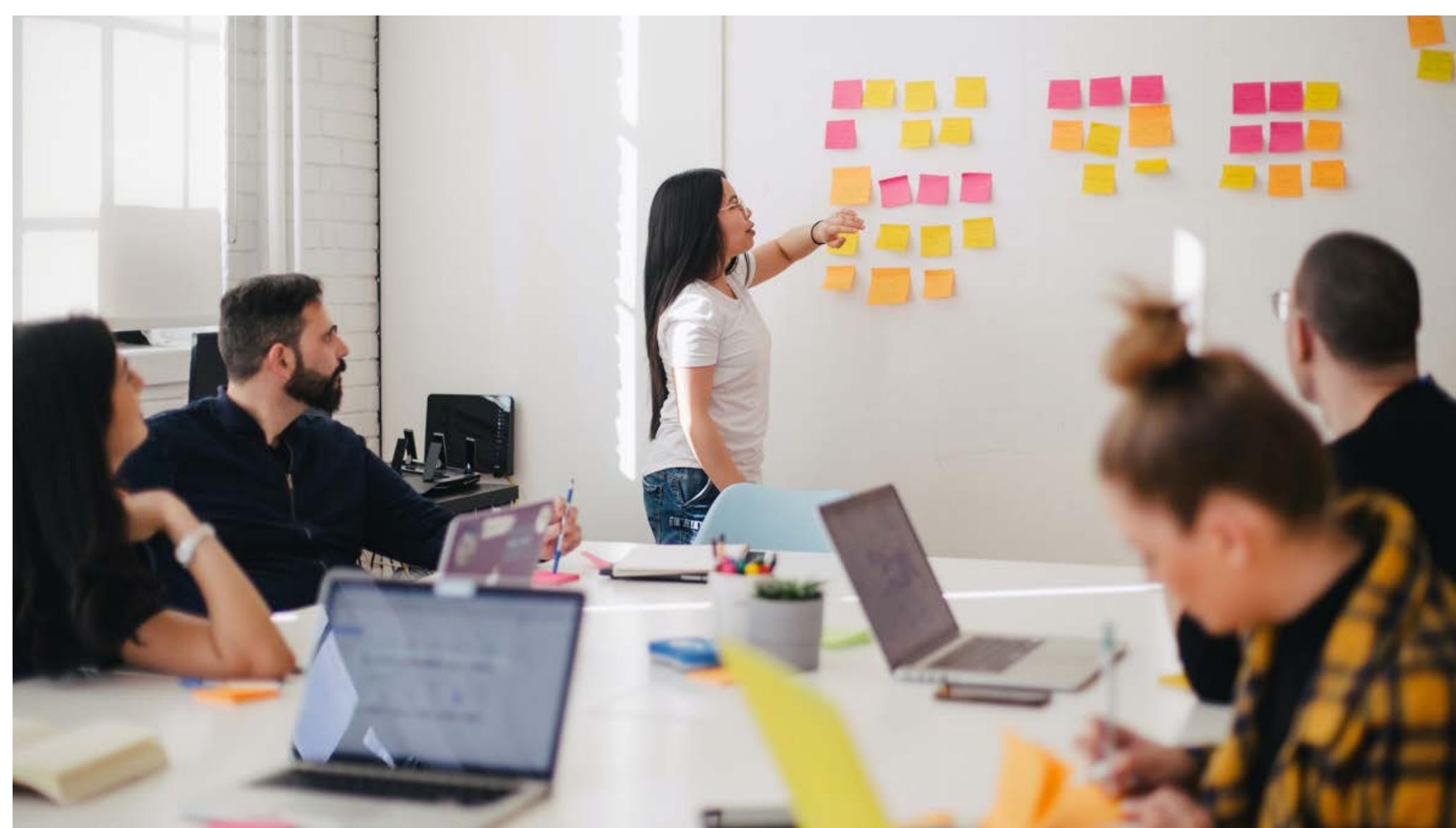


EVALUATION OF THE NEEDS FOR CHANGE IN ORGANISATION

The results of the evaluation of organisation survey revealed that the highest

ganisations was achieved in France (71\%), slightly lower in Portugal (69\%) and notably lower in Italy and Poland (67\%). All results can be classified as good.

Figure 7. Evaluation of Organization

General Average Score - Country Comparison

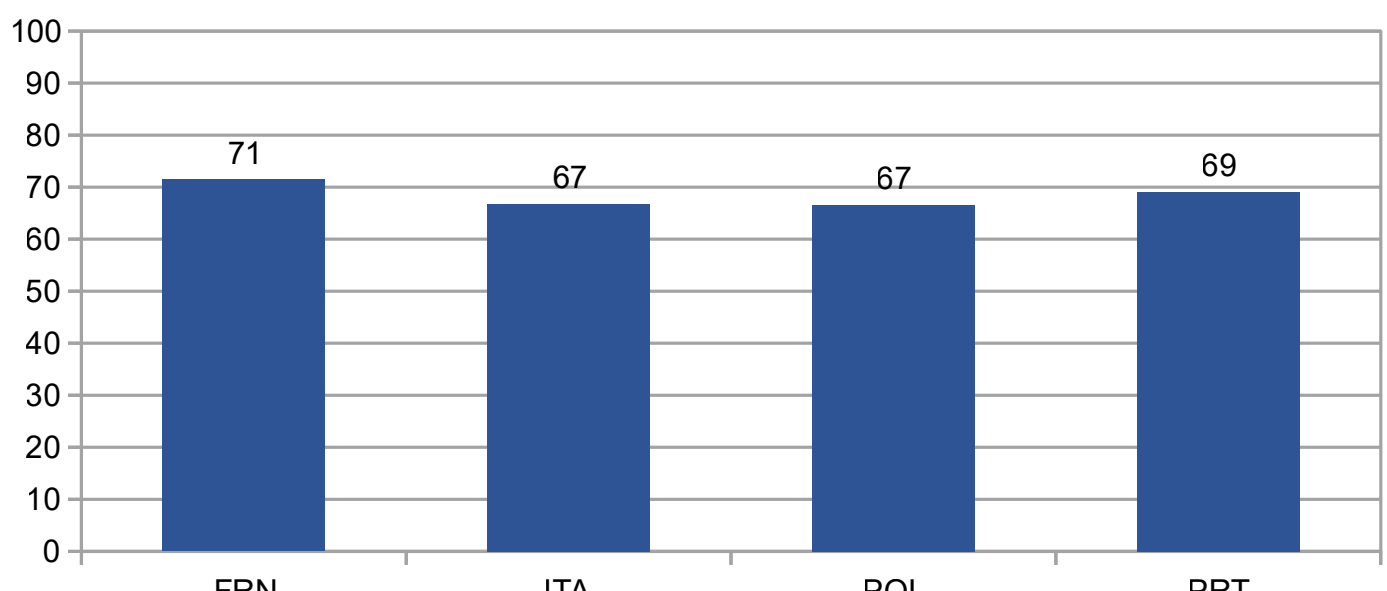

FRN

ITA

POL

PRT

Upon the division into categories (Figure 8) the results revealed a high variety of score in numerous areas. The biggest appreciation of the employer was noted in France $(73 \%)$ and the lowest in Poland (58\%). A visibly higher appreciation by the leader was noted in France $(75 \%)$ than in any other country. Achievement of goals in the organisation was highest in Italy and Poland (80\%). Achievement of personal success was highest in France (72\%). The biggest feeling of responsibility was observed in the Polish respondents $(91 \%)$. The level of independe highest in the vancement opportunities (65\%). The personal development possibilities were perceived most positively by the Polish respondent $(79 \%)$. Development strategy of the organisation was evaluated the highest by both Pol- ish (65\%) and Portugal (66\%) respondents. Development continuity was highest in Portugal $(67 \%)$. The workplace achieved the highest score in France (76\%), whereas the comfort of work was equally praised in France and Portugal $(81 \%)$. The salary was assessed best in France (57\%), which can be considered as a low score. Benefits and bonuses scored low in all countries, ranging from $35 \%$ to $43 \%$. Relationship with the boss is best viewed in Portugal (77\%), whereas the relationship with colleagues scored nearly equally in all countries, ployment security is surprisingly the same in France, Italy and Portugal (71\%), with a notably lower result in Poland ( $65 \%$ ). The highest negative impact of work on personal life was noted in Poland (40\%), while the lowest impact occurred in France (23\%).
Figure 8. Evaluation of Organization Categories Average Country Score Comparison

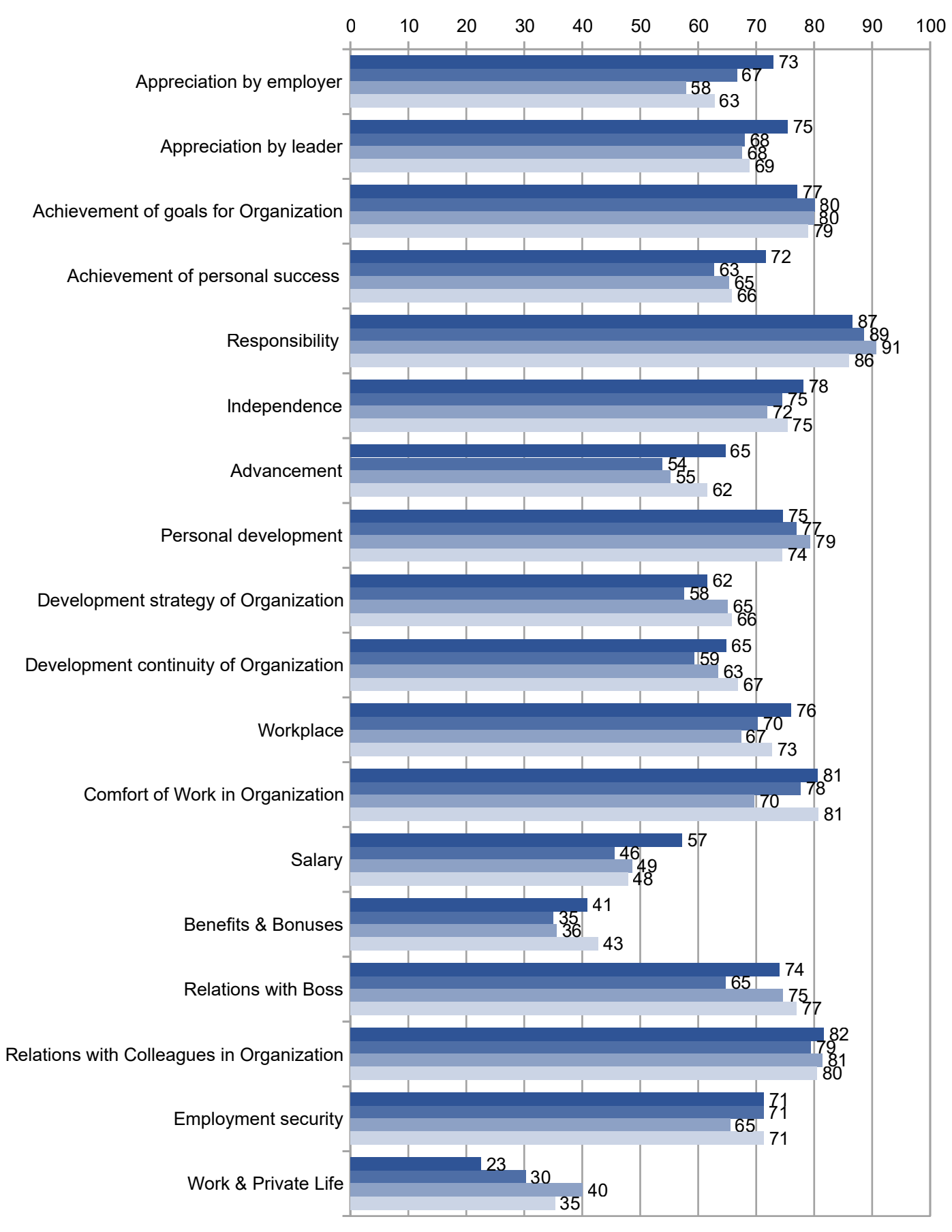

$\varpi \mathrm{PRT} \backsim \mathrm{POL} \backsim \mathrm{ITA} \backsim \mathrm{FRN}$ 
PROFILE OF THE ADULT EDUCATION ORGANISATION IN THE RESPECTIVE COUNTRIES

Image 9. Evaluation of Organization

Comparison of Scores based on Type of Organization

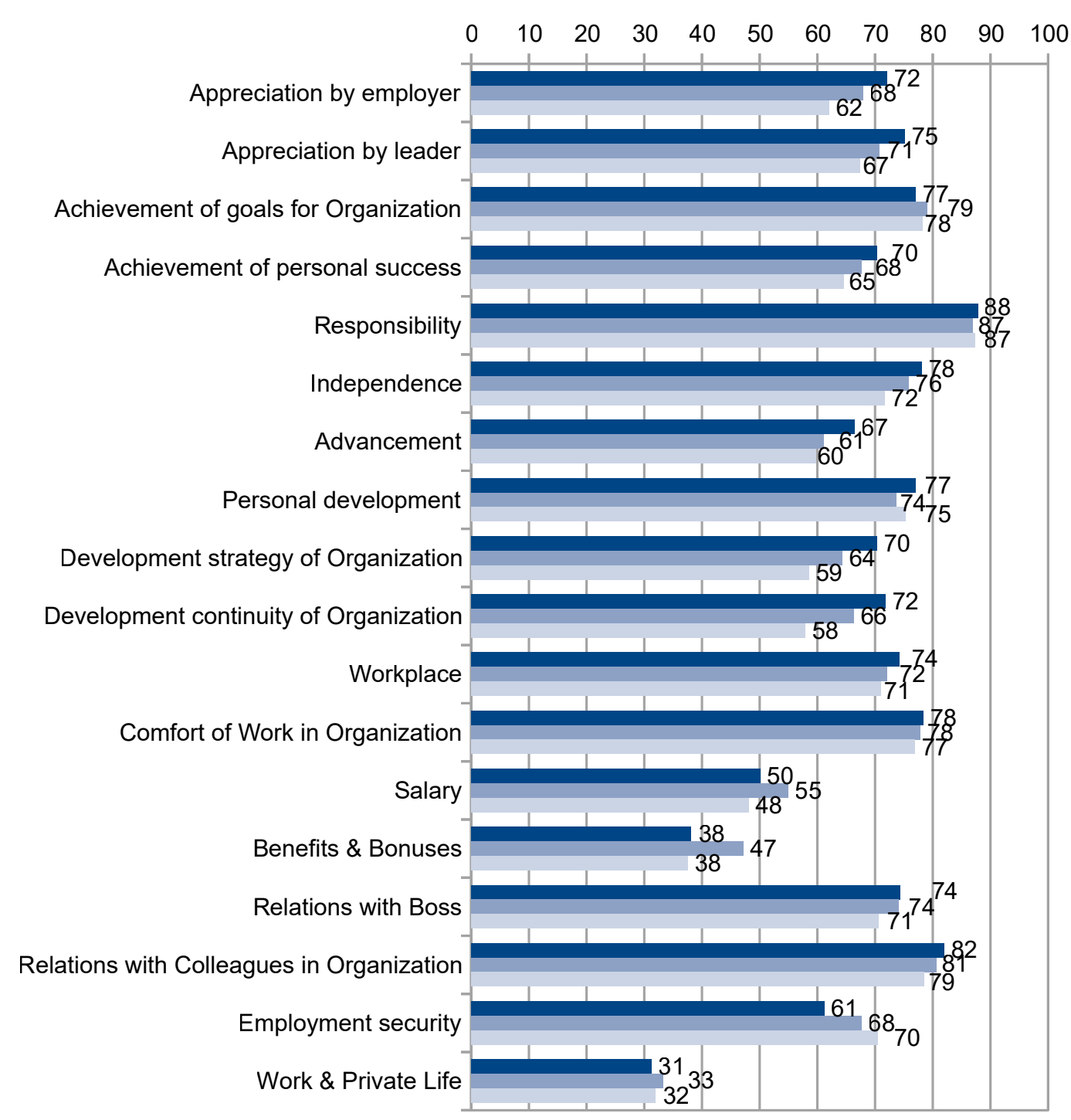

$\square$ State $\square$ Private $\square \mathrm{NGO}$
On the basis of the collected data, it is possible to draw preliminary conclusions regarding the types of adult education institutions in the project partners' countries.

The respondents in Poland equally identified different types of organisations (39 private, 32 state and $33 \mathrm{NGO}$ ).

In France and Italy, adult education organisations were mostly identified in the private sector. In France, the respondents identified 98 private, 39 state and $36 \mathrm{NGO}$ organisations, whereas in Italy there were 51 private, 44 state and $38 \mathrm{NGO}$ organisation.
In Portugal, there was a disproportion between the number of private (54) and NGO (50), and state organisations (34)

This comparison indicates that the sector of NGO adult education was the least represented (with Portugal being an exception), while the private sector was the most represented. The biggest disproportion between the types of evaluated organisations occurred in France, whereas the smallest in Poland.

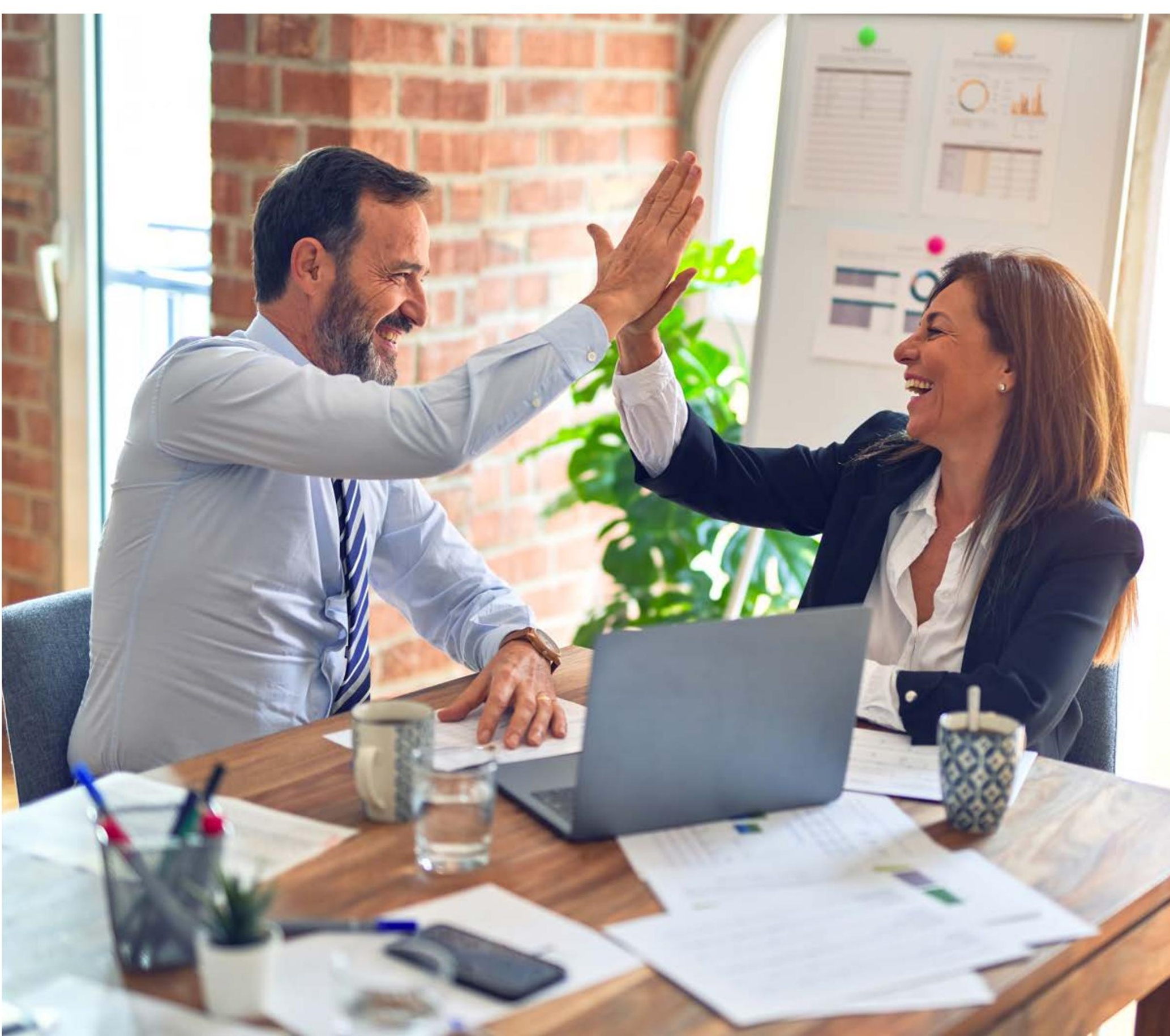


Image 10. Types of organization evaluated by respondents

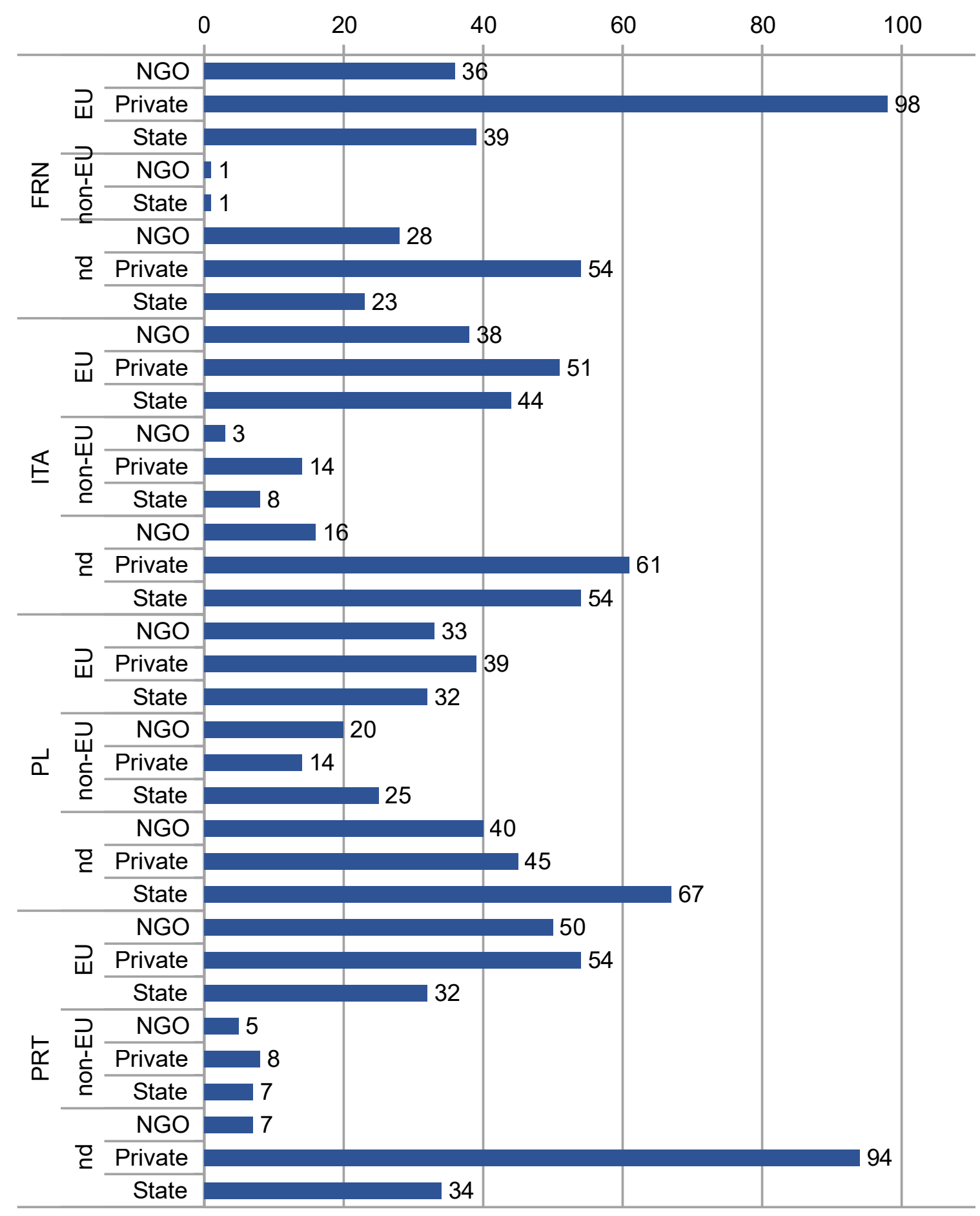

The comparison of the evaluation of the respective organisation types regarding their need for change shows that in most cases non-governmental organisations are better assessed than other types of organisations. The strongest need for change is

indicated by the respondents in regard to the state institutions. These trends differ when it comes to purely economic indicators. Non-governmental organisation are evaluated as the worst regarding salary, bonuses and employment security. This indicates higher needs for change in this regard in NGOS, e.g. in the form of financial aid or increased employment security. 
3. Summary 
The research project aimed to diagnose the education needs of adult educators and NGO workers and to quantitatively evaluate their organisations. The results served as a basis for three analyses: 1) general scores obtained by all participants; 2) general scores obtained by the EU- and non-EU citizens; 3) generals scores obtained by the respondents representing the nationalities of project partners.

The first part-the general level of analysis taking into account scores obtained by al participants-revealed that the lowest education needs were connected to digital competences $(82 \%)$, whereas the highest need were connected to entrepreneurship competences $(73 \%)$. The evaluation of organisation indicated that participants were highly satisfied with responsibilities they had $(87 \%)$ while the lowest satisfaction was connected to the benefits and bonuses ( $42 \%$ ) and salary $(51 \%)$.

The second part, which focused on the comparison between the EU and non-EU citizens, revealed that for most of the investigated categories the level of satisfaction was higher in EU participants. The exception occurred in regard to the multi-language and multi-cultural competences, which was higher by $1 \%$ in non-EU citizens. The evaluation of organsations indicated mostly higher appreciation of the organisation by EU citizens, with a notable exception in the categories of achievement of personal success $(+4 \%)$ and benefits and bonuses $(+6 \%)$ in favour of non-EU organisations.

The third level of the analysis-focused on the participants representing nationalities of the project partners-revealed that educatio needs were best satisfied in France $(71 \%)$ Notably lower scores were noted in both Italy and Poland (67\%). The analysis of scores in their respective subcategories revealed the following: in France, the highest needs were related to the entrepreneurship competences; in Italy and Poland, the highes needs were concerned with the multi-language and multi-cultural and entrepreneurship competences; in Portugal, the ugal, the highest needs were related to the multi-language and multi-cultural, and the entrepreneurship competences as well as the openness to science and culture.

Regarding the evaluation of the organisation the scores varied so greatly that only significant assessments were taken into account; as a result, the significant disproportions were found in the following areas:

1) appreciation by the employer

2) appreciation by the leader:

3) achievement of personal success:

4) advancement;

5) development strategy of the organisation 6) development continuity of the organisation 7) workplace conditions

8) comfort of work;

9) salary;

10) benefits and bonuses;

11) relationship with the boss;

12) employment security; and

13) impact of work on personal life.

Results clearly show that the general levels of adult educators' education needs are satisfactory; the same is true for the evaluation of organisations. Yet there is still room for improvement, especially in the areas of multi-language and multi-cultural and entrepreneurship competences. Therefore, it is recommended that future educational projects aiming at the improvement of the needs of adult educators focus especially on those areas. The major weaknesses of organisations employing adult educators and adult education sector workers are located in the areas of wages and financial bonuses, which (ang at a critical level and are an important part of one's sense of ma- terial security and, hence, may be an important factor in attracting competent indviduals to this type of activity. Additionally, we should pay attention to the stark contrast between the constant underfinancing competences of their educators, hence the situation in which the organisations do not meet the financia expectations of their employees.

The needs of the EU citizens are generally more satisfied than the needs of the non-EU citizens; the former also display more praise

for their organisations. On the other hand, their level of achievement of personal success is lower, which implies that EU adult educators and NGO workers do not connect their activity so strongly with personal success, which in turn may have cultural or economical premises.

Lastly, if we take into account only the participants representing countries of the project partners, there is a significant prenise the following areas:

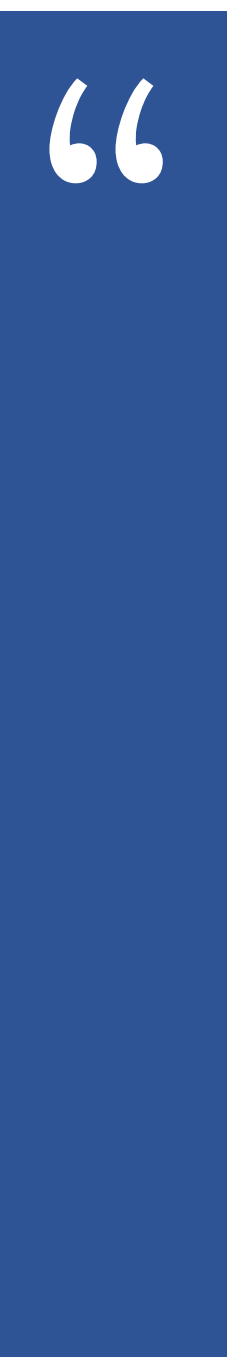

च appreciation by an employer, especially in Poland;

च appreciation by a leader, in all diagnosed countries except for France;

च achievement of personal success, especially in Italy;

advancement, especially in Italy and Poland;

development strategy of the organisation, especially in Italy;

У development continuity of organisation area, especially in Italy;

चorkplace conditions, especially in Poland

च comfort of work in organisation, especially in Poland;

च salary conditions in all diagnosed countries;

च benefits and bonuses, which were evaluated poorly in all countries;

च relationships with the boss, especially in Italy;

च employment security, especially in Poland;

the impact of work on private life, especially in Poland. 
The report was evaluated by an independent evaluator, Tijana Milenkovic Jankovic (UK). The evaluator worked in various international, educational projects (further and adult education) for more than twenty years. This working experience provided her with the opportunity to gain insight and understanding about the functioning of

\section{Her main conclusions are:}

1. AENI provides a solid general insight in the adult educators needs. Even though the general results for AENI test show mainly high results in all partners countries, the results are based on the self-assessment. (...) Received results can be an indication to stakeholders in partners countries about the most needed skills for adult educators that can serve for planning how to improve them within the initial elucation, improve them within the initial education, as well as in Continuous Professional Development (CPD) courses for adult educators, but also to support the process of validation of competences acquired in different contexts (Council Resolution, 2011). (...) On a general level, scores from AENI test can be classified as good. However, a particular need is identified in reference to the multi-language and multi-cultural competences (ML\&MC) and Entrepreneurship Competence (EC). (...) educational institutions and organisations in various sectors and all phases of the education cycle. She gained experience in the area of evaluation as an independent consultant within the Project Evaluation of the UNHCR Vocational Training Programme in Serbia and as a Lux-Development Freelance Regional / National Consultant in Montenegro.

2. It is key that organisations involved in the research receive the results of the study and have a chance to compare them with general, general, country-level outcomes, but also with those of other countries. The study outputs can serve them to reflect on results and make the action plans to improve the situation in the organisation.(...)

3. AENI provides a solid general insight in the adult educators needs. Even though the general results for AENI test show mainly high results in all partners countries, the results are based on the self-assessment. (...)The quantitative instrument developed for the evaluation of organisations provided a valid of basefor the preparation of the qualitative research. 
4. References

\section{REFERENCES}

wet 
Bacigalupo, M., Kampylis, P., Punie, Y., \& Van den Brande, G. (2016). EntreComp: The entrepreneurship competence framework. Luxembourg : Publication Office of the European Union, 10, 593884

Bassett-Jones, N., \& Lloyd, G. C. (2005),Does Herzberg's motivation theory have stayin power? Journal of Management Development, Vol. 24 Iss 10 pp. 929-943, http://dx doi.org/10.1108/02621710510627064

Buiskool, B. J., Broek, S. D., van Lakerveld, J.A Zarifis, G. K., \& Osborne, M. (2010). Ke competences for adult learning professionals. Contribution to the development of a reference framework of key competences for adult learning professionals, 157

Burns, D. (1985). Intimate connections. New York: Signet (Penguin Books)

Caena, F. (2013). Supporting teacher competence development for better learning outcomes. Education \& Training, European Commission, p. 5-59.

Council of Europe. Council for Cultura Co-operation. Education Committee. Modern Languages Division. (2001). Commo European Framework of Reference for Languages: learning, teaching, assessment. Cambridge University Press.

Council of the European Union. (2018). COUNCIL RECMMENDATIONS, 22 May 2018, with reference to key competences in the process of life-long learning. (2018/C 189/1). Official Journal of the European Union, pp. 1-13

Council Resolution on a renewed European agenda for adult learning $\mathrm{OJ} C \mathrm{C} 32$, 20.12.2011, p. 1-6.

EU Science Hub - European Commission. 2020. Entrecomp: The Entrepreneurship
Competence Framework. - EU Science Hub - European Commission. [online] Available at: <https://ec.europa.eu/jrc/en/publication/eur-scientific-and-technical-researchreports/entrecomp-entrepreneurship-competence-framework $>$ [Accessed 15 November 2020].

Europa.eu. 2020. Common European Framework of Reference. Europass. [online] Available at: <https://europa eu/europass/en/common-european-frameworkreference> [Accessed 15 November 2020].

Faure, E., Herrera, F., Kaddoura, A. R., Lopez H., Petrovski, A. V., Rahnema, M., \& Ward, F. C. (1972). Learning to be: the world of education today and tomorrow. Paris: UNESCO.

Głomb, K. (2020). Edukacja dla Przemystu 4.o. Wyzwania dla Polski [Education for Indus-try 4.o A Challenge for Po land]. Warszawa: Agencja Rozwoju Przemystu.

Griffith, W. S. (1978). Educational Needs: Definition, Assessment, and Utilization. The School Review, 86(3), pp. 382-394.

Hakio, K., \& Mattelmäki, T. (2019). Future Skills of Design for Sustainability: An Awareness-Based Co-Creation Approach. Sustainability(11), pp. 1-24.

Herzberg, F., Mausner, B. and Snyderman, B. (1959), The Motivation to Work, Wiley, New York,NY.

Hipkins, R. (2018). How the key competencies were developed: The evidence base. Wellington: New Zealand Council for Educational Research.

Kobylarek, A. (2009). Kompetencje komunikacyjne w systemie umiejętności nauczyciela tem of teachers' abilities]. In K. Błaszczyk,
M. Drzewowski, \& W. Maliszewski, Komunikacja spoteczna a zarządzanie we wspótczesnej szkole [Social communication and management in a modern school] (pp. 334342). Toruń: Adam Marszałek.

Martowska, K., \& Matczak, A. (2013). Pomiar kompetencji społecznych - prezentacj nowego narzędzia diagnostycznego [Measuring social skills - presentation of a new diagnostis tool]. Psychologia Jakości Życia [Psychology of the Quality of Life] (1), pp. 43-56.

Morris, E. (2001). Special Educational Needs Code of Practice. London: Department for Education and Skills.

Nijssen, A., van Lakerveld, J. A., Buiskool, B. J. den Oudendammer, F., Broek, S. D., \& Hake, B. (2008). ALPINE - Adult Learning Profession in Europe: A Study of the Current Situation, Trends and Issues. Project Report. Research voor Beleid, Zoetermeer, Netherlands.

Padzik, K. (2016). Ocena zintegrowana Assessment i Development Center. Warszawa: Wolters Kluwer.

Paterson, R. (2000). The Assertiveness Workbook: How to Express Your Ideas and Whe tionships. Oakland: New Harbinger.

Petrètiène, A., Daukšienė, J., \& Grašienė, J. (2020). Creativity and speciality language in the context of the development of key competences. Mokslas - Lietuvos ateitis(12), pp. 1-7.

Radovan, M. (2019). Cognitive and Metacognitive Aspects of Key Competency "Learning to Learn”. Pedagogika(1), pp. 28-41.

Stufflebeam, D. L., McCormick, C. H., Brinkerhoff, R. O., \& Nelson, C. O. (2012). Conducting Educational Needs Assessments. Springer.
Warzocha, T. (2016). Kompetencje komunikacyjne jako komponent kompetencji społecznych nauczycieli akademickich - założenia do badań [Communication skills as a component of social skills for academic teachers - a foudation for research]. Edukacja Technika - Informatyka [Education - Engineering - Information Technologies] (2), pp. 70-75 
5. Annexes

\section{ANNEXES}

wet 
(Adults Education Needs Inventory)

Questionnaire to study training needs in the field of key competences of adults

Below is a list of 39 statements. Please indicate how far you agree with each statement on a scale of 1 to 5 ( 1 = decidedly do not agree,

$\mathbf{5}=$ decidedly agree). There are no good or

be

too much time on each statement, but give the answer which first comes to mind. This research is completely anonymous, and the results will be used exclusively for scientific purposes.

NOTE: Please give answers to all the statements

1 = decidedly do not agree, 5 = decidedly agree

$\begin{array}{llllll}1 & 2 & 3 & 4 & 5\end{array}$

CC I can have a conversation in any situation (eg. in a conflict, or when my interlocutor has a different opinion)

CC I consider that I can send clear and understandable

messages

3 SCC When seeking information I try to use various sources

CC Very often I experience a situation when it is difficult

to express my thoughts

5 CC I usually don't have a problem in understanding my interlocutor

$6 \quad$ CC I enjoy discussing with various people

$7 \quad$ CC I feel at ease when conversing with other people

8 CC I can express my thoughts in an unconventional way

MM I am fluent in speaking and writing more than one

foreign language

OSC I consider that I do not need to develop my knowledge

anguages

11 MM I seize different opportunities in learning foreign

11 languages

12 MM I like learning new languages

I use a foreign language every day (e,g, watching films, reading books) 
14R OSC I consider that maths do not help in uncovering the truth

OSC There are justifiable doubts concerning certain

$5 \mathrm{R}$ theories, e.g. human influences on the climate, or the use of vaccination

16 EC I consider that effective action requires a clear and

unambiguous plan

17R EC I sometimes act illogically

18 SCC I often use various sources when planning

19 EC I generally follow a pre-determined plan

DC I know how to use the new technologies for more

effective communication

21 DC I use various technological innovations

22 DC I feel that I am competent enough in information technology

23 DC I can easily use the most common devices (PC, smartphone, laptop, tablet, etc.)

24 CC I can work in a group

CC I think that it is difficult for me to form relationships

25R with other people

ER I I am sometimes difficult in relationships with other

people

27R OSC It is impossible to reconcile EU integration policy with cultural distinctiveness

28 SCC I engage in social issues which are important to me

29 SCC I feel that I have an effect on my surroundings

30 CC I can motivate others to realize common aims

31 CC I am effective in negotiations

$32 \mathrm{R}$ OSC The world does not offer many possibilities to realise

my ideas

33R EC I don't like the planning stage

34R EC I consider that controlling and monitoring work are

34R generally pointless

EC I sometimes have a feeling of my own mismanagement when carrying out a task

36R CC I rarely give feedback to my co-workers

37 MM I am interested in various cultures

38R OSC I would not be able to express myself in any form of art

$39 \mathrm{R}$ OSC For me, contemporary culture is worthless

CC Communication competences (max. 60 pts.): 1, 2, 4R, 5, 6, 7, 8, 24 25R, 30, 31, 36R

MM Multilingualism and multiculturalism (max. 25 pts.): 9, 11, 12,13, 37

DC Digital competences (max. 20 pts.): 20, 21, 22, 23

EC Entrepreneurship competences (max. 35 pts.): 16, 17R, 19, 26R, 33R, $34 \mathrm{R}, 35 \mathrm{R}$

OSC Openness to science and culture (max. 35 pts.): 10R, 14R, 15R, 27R 32R, 38R, 39R

SCC Social and civil competences (max. 20 pts.): 3, 18, 28, 29

R Reverse score

\section{NTERPRETATION OF THE RESULTS}

Standardisation research is currently being carried out on a group representing educators from various European countries. At this tage, the aathas propose interim norms to help in converting the raw data. Depending on the number of points gained in each particular class, it is possible to allocate the results to one of three groups - high, medium and low. Low results indicate a low level of competen. evel of competence in a particular educator and therefore, an increased need to improve that competence.

Interpretation of results

\begin{tabular}{|lccc|} 
& low & medium & high \\
\hline CC & $12-13$ & $32-41$ & $42-60$ \\
\hline MM & $5-13$ & $14-17$ & $18-25$ \\
\hline DC & $4-10$ & $11-14$ & $15-20$ \\
\hline EC & $7-18$ & $19-24$ & $25-35$ \\
\hline OSC & $7-18$ & $19-24$ & $25-35$ \\
\hline SCC & $4-10$ & $11-14$ & $15-20$ \\
\hline
\end{tabular}


Below are 18 statements concerning your opinion on your place of work. Please indicate how far you agree with each statement

\section{NOTE: Please give answers to all the statements}

$1=$ decidedly do not agree, 5 = decidedly agree $\begin{array}{lllll}1 & 2 & 3 & 4 & 5\end{array}$

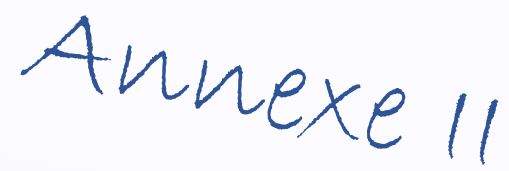

n a scale of 1 to $5(1=$ decidedly do not agree, 5 = decidedly agree)

\begin{tabular}{|l|l|}
\hline 40 & I feel appreciated by my employer \\
\hline 41 & I feel appreciated by my immediate boss (manager, leader, etc.) \\
\hline 42 & I completely achieve the goals set by my employer \\
\hline 43 & My workplace allows me to achieve professional success \\
\hline 44 & I feel responsible for my position and the tasks allotted me \\
\hline 45 & I feel independent when carrying out the tasks allotted me \\
\hline 46 & My employer gives me an opportunity for advancement \\
\hline 47 & $\begin{array}{l}\text { My current job affects my personal development (extending } \\
\text { knowledge, learning something new) }\end{array}$ \\
\hline 48 & $\begin{array}{l}\text { My employer has a precise direction in the development of } \\
\text { the organization }\end{array}$ \\
\hline 49 & $\begin{array}{l}\text { My employer does not rest on his/her laurels and continu- } \\
\text { ally develops the organization }\end{array}$ \\
\hline 50 & My position at work is suited to my duties \\
\hline 51 & I feel comfortable in carrying out my duties at work \\
\hline 52 & I earn decent money in my organization \\
\hline 53 & The organization offers me attractive benefits and bonuses \\
\hline 54 & My direct relationship with my boss is satisfactory \\
\hline 55 & $\begin{array}{l}\text { My direct relationships with colleagues on the same posts } \\
\text { are satisfactory }\end{array}$ \\
\hline 56 & My organization guarantees me employment security \\
\hline 57 & My work has a negative effect on my private life \\
\hline
\end{tabular}


Select / enter as appropriate

58. Gender $\square \mathrm{M} \quad \square \mathrm{F}$

59. Age ….......

60. Type of Organization $\quad \square$ state

$\square$ Private

$\square \mathrm{NGO}$

61. Position held (mark one):

\begin{tabular}{l|l}
\hline $\begin{array}{l}\text { Owner / Director of the orga- } \\
\text { nization }\end{array}$ & \\
\hline Middle manager & \\
\hline Employee & \\
\hline Volunteer & \\
\hline
\end{tabular}

\section{INTERPRETATION OF THE RESULTS}

Scores are represented in percentage values. Each item can have a minimum score of $\mathrm{o} \%$ and a maximum score of $100 \%$. The higher the score the indvidual obtains, the better his or her opinion about his or her organisation is. The only exception is the last category, work and private life; in this category, the lower the obtained score is, the weaker the influence of the work on one's private

It is recommended to interpret obtained scores in the evaluation of organisations as follows:

$\mathbf{0 - 2 0} \%$ - very low - very low opinion about organisation/employer

21-40\%-low-low opinion about organisation/employer

41-60\% - medium - neutral opinion about organisation/employer

61-80\% - high - high opinion about organisation/employer

$\mathbf{8 1 - 1 0 0 \% ~ - ~ v e r y ~ h i g h - ~ v e r y ~ h i g h ~ o p i n i o n ~}$ about organisation/employer

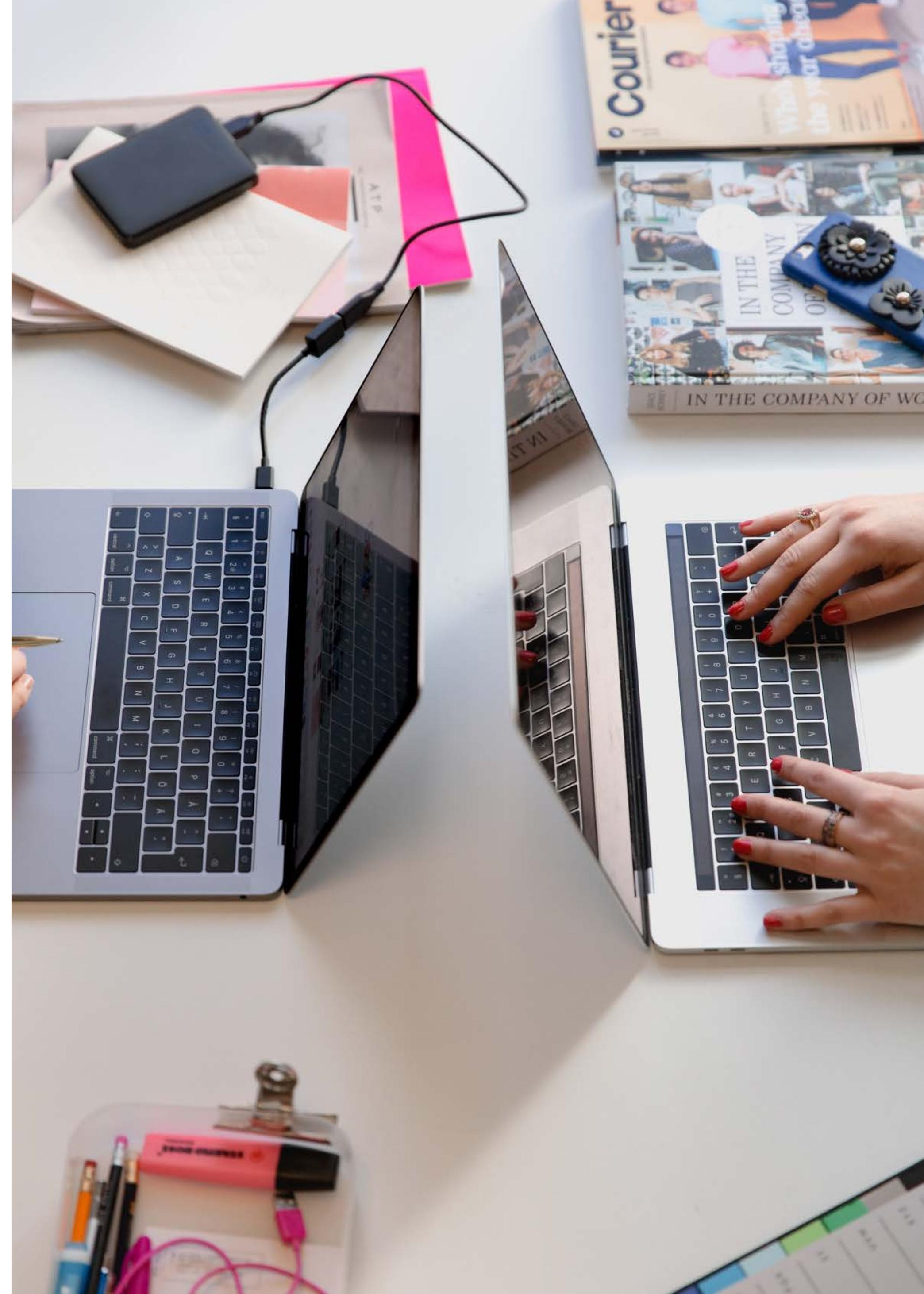



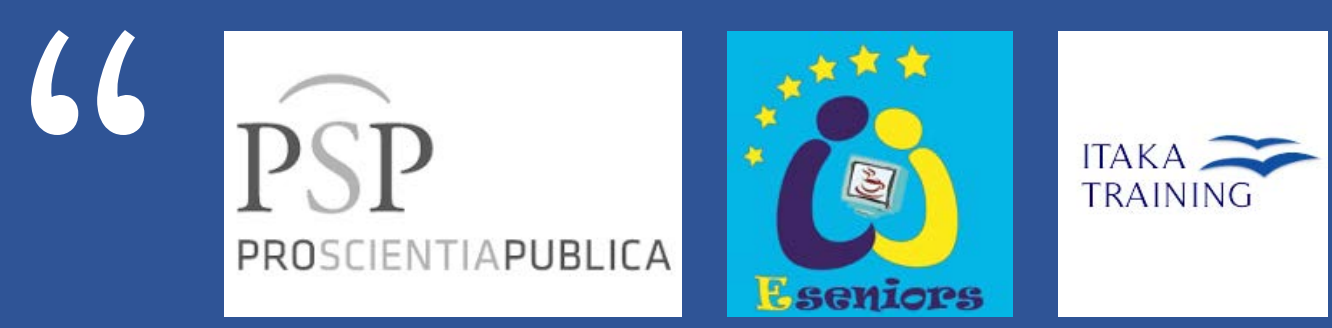

ISBN 978-83-953451-4-2 